University of Wollongong

Research Online

Faculty of Social Sciences - Papers (Archive) Faculty of Arts, Social Sciences \& Humanities

2015

Same but different: sources of natural resource management advice for lifestyle oriented rural landholders

Victoria Ikutegbe

University of Wollongong, vui982@uowmail.edu.au

Nicholas J. Gill

University of Wollongong, ngill@uow.edu.au

Peter Klepeis

Colgate University, pklepeis@colgate.edu

Follow this and additional works at: https://ro.uow.edu.au/sspapers

Part of the Education Commons, and the Social and Behavioral Sciences Commons

Research Online is the open access institutional repository for the University of Wollongong. For further information contact the UOW Library: research-pubs@uow.edu.au 


\title{
Same but different: sources of natural resource management advice for lifestyle oriented rural landholders
}

\begin{abstract}
Amenity migration to attractive and accessible non-metropolitan areas changes social and environmental relations with consequences for natural resource management and landscape composition and trajectories. Lifestyler oriented rural landholders are often cast as a problem for land management and extension. Managers and some researchers see them as a cause of landscape and social fragmentation and report difficulties in engaging such landowners on natural resource management issues and responsibilities. In contrast, limited existing research indicates that lifestylers do join and form networks of personal and other contacts for advice and support in land management. We contribute to this research with a survey of rural landholders in southeastern New South Wales (NSW). We explicitly compare the sources of advice for land management for lifestylers with those of farmers. We focus on the types of sources available to rural landholders in Australian regions and their relative importance to these two landholder groups. We find that lifestylers and farmers are different in their sources of advice but that both prefer personal sources rather than sources such as agencies. We reflect on the significance of the differences for engagement with lifestyle oriented rural landowners and for understanding landscape change.
\end{abstract}

\section{Keywords}

advice, management, resource, natural, sources, different, but, same, lifestyle, landholders, rural, oriented

\section{Disciplines}

Education | Social and Behavioral Sciences

\section{Publication Details}

Ikutegbe, V., Gill, N. \& Klepeis, P. (2015). Same but different: sources of natural resource management advice for lifestyle oriented rural landholders. Journal of Environmental Planning and Management, 58 (9), 1530-1543. 
Same but different: sources of natural resource management advice for lifestyle oriented rural landholders 


\begin{abstract}
Amenity migration to attractive and accessible non-metropolitan areas changes social and environmental relations with consequences for natural resource management and landscape composition and trajectories. Lifestyler-oriented rural landholders are often cast as a problem for land management and extension. Manager and some researchers see them as a cause of landscape and social fragmentation and report difficulties in engaging such landowners on natural resource management issues and responsibilities. In contrast, limited existing research indicates that lifestylers do join and form networks of personal and other contacts for advice and support in land management. We contribute to this research with a survey of rural landholders in south-eastern NSW. We explicitly compare the sources of advice for land management for lifestylers with those of farmers. We focus on the types of sources available to rural landholders in Australian regions and their relative importance to these two landholder groups. We find that lifestylers and farmers are different in their sources of advice but that both prefer personal sources rather than sources such as agencies. We reflect on the significance of the differences for engagement with lifestyle-oriented rural landowners and for understanding landscape change.
\end{abstract}

Key Words: Amenity migration; hobby farming; engagement; extension; multifunctional landscapes 


\section{Introduction}

Rural amenity migration, the movement of people based on the draw of natural and/or cultural amenities, is a significant feature of rural demographic and land ownership change in both developed and less developed countries (Abrams et al. 2012). In Australia, this population movement and growth is spatially concentrated, with growth in regions on the east coast, particularly in the south-east, and in the south-west, as well as in some relatively accessible and high amenity inland areas (Race, Luck, and Black 2011). Amenity migration has significant environmental implications for the receiving areas. This is because the social and environmental relations that inform land use, land management, and natural resource governance and politics are recast by the aspirations, values, and activities of these 'new rural landowners' (for both overviews and case studies see, for example, Abrams and Gosnell 2012; Walker and Hurley 2011; Robbins et al. 2009; Abrams et al. 2012; Klepeis, Gill, and Chisholm 2009; Gill, Klepeis, and Chisholm 2010; Epanchin-Niell et al. 2010; Barr 2010; Argent 2011). As a result of these changes, land use and land management patterns shift, subdivision and residential development often increases, socio-economic settings change with rural gentrification, and conflicts can emerge over development and environmental issues. In this paper our focus is those social relationships that may influence land use and land management decisions by landowners. Such relationships include the relationships among landowners and between landowners and others such as agency staff and other managers (Abrams et al. 2012; Dwyer and Childs 2004). These relationships are important for the environmental subjectivities and institutions that develop in amenity migration areas and for the material practices and landscapes that result. This is evident, for example, in crossboundary wildlife and vegetation management institutions, environmental learning, invasive plant and fire management, and riparian management (Abrams et al. 2012). This paper complements a small but developing literature on these social relationships and their implications for environmental management. It provides analysis of survey data regarding the sources that landowners rely upon for advice and information.

Lifestyle landowners have been shown to differ from farmers in their land management aspirations and practices (Mendham and Curtis 2010; Gosnell, Haggerty, and Travis 2006). In general, the characteristics of lifestylers include 'limited, if any, dependence on farm income... and a focus on landownership for “lifestyle” reasons’ (Gill, Klepeis, and Chisholm 2010). Some of the 'lifestyle' reasons reported by lifestyle farmers include 'more 
pleasant climate', 'more relaxed lifestyle' and 'attractive physical environment' (Curry, Koczberski, and Selwood 2001). These reasons and the characteristics of lifestyle landowners serve as motivations for the way in which they use and manage their land. The motivations and land uses of professional farmers, on the other hand, stem to a greater extent from the fact that they depend on the land for their livelihood. This comparative diversity in landholders' reasons for owning rural land, and where they seek advice with regards to what they actually do on their land, forms the basis for this paper. As part of an ongoing project that will investigate such extension efforts in more depth than afforded by a survey, particularly in relation to invasive plants, this paper has three key aims. Our first aim is to demonstrate the relative importance of various sources of advice and information regarding land and natural resource management among landholders. Our primary focus is lifestyle landholders but we will also address a second aim, which is to analyse the extent to which lifestylers' key sources of advice differ from that of farmers. Finally, our third, and more methodological aim is to explore these issues using and comparing two different means of distinguishing between landholder types - the significance of land-based income and best description of land use. Studies to date have either used non-exclusive a priori descriptive landholder typologies (or have deductively developed them) or have assumed that variables such as length of ownership provide sufficient distinction between landowner types.

\section{Reaching Lifestylers}

Among natural resource management (NRM) agencies, and other organisations, there are concerns about the land use and land management practices of these new landowners (Abrams et al. 2012). In the past, extension professionals have reported difficulty in engaging lifestylers (Pannell and Wilkinson 2009). This has been attributed, inter alia, to low prioritisation given to land management skills development compared to 'lifestyle' aspects of land ownership, lack of knowledge, absentee ownership, other demands on their time, land ownership aspirations that do not always relate well to NRM programs and projects, and also to public sector trends that have marginalised such landholders from mainstream extension programs (Pannell and Wilkinson 2009; Meadows, Herbohn, and Emtage 2012; Graham 2013; Hollier and Reid 2007). However, lifestyle rural landholders constitute the majority of landholders in some regions, can account for significant proportions of rural land in those regions, can be enthusiastic about environmental issues, and their land may contain areas of ecologically valuable native vegetation (Lake 2009; Meadows, Herbohn, and Emtage 2012; 
Hollier and Reid 2007). In such circumstances and particularly where significant public benefits may be derived from extension services, effort expended in engaging lifestyle rural landholders is worthwhile (Pannell and Wilkinson 2009). Organisations such as local governments, state agencies such as catchment management authorities and NGOs are targeting lifestyler landholders through means such as booklets on rural living, networks such as regional and local Bushcare and Landcare associations, private land conservation programs, and bridging organisations such as the Small Farms Network in south-eastern NSW. There has however been relatively little assessment of such efforts to engage lifestylers, nor has there been much research to investigate the ways in which lifestylers learn about their land and natural resource management, the relative influences of various sources and vehicles of advice and information, and of the networks that lifestylers are part of. This paper contributes to this area with results regarding the key contacts for lifestyler landowners for land management.

Much of what is known about the outcomes of engagement with lifestyler landowners in Australia comes from Victoria (Hollier and Reid 2007). This project found that lifestylers were not part of the same networks as farmers and that friends, closely followed by neighbours, were the key sources of information for lifestyler landowners. Other important sources of information were books, brochures and field days, while rural stores and state government agencies were relatively important institutional sources. These findings are consistent with what is known more generally in landholder extension - that personal networks are important influences on landholder practice and adoption (Pannell et al. 2006). The importance of informal social networks among lifestylers for learning about land and environmental management has also emerged from work in south-eastern Queensland where an in-depth study of landholders on residential estates found that 'most landholders preferred to obtain much of their needed information and assistance from groups of like-minded smallacreage landowners’ (Meadows, Herbohn, and Emtage 2012, p.12; Meadows, Emtage, and Herbohn 2014). Similarly, in socially diverse landscapes in NSW and Victoria relationships among landowners were central to effective collective invasive plant management (Graham 2013). Long term work in Colorado has further highlighted the role of interpersonal and collaborative learning and action among landowners in 'exurban' landscapes (Larsen et al. 2011; Larsen et al. 2007). Through a diverse range of interactions in a variety of settings including informal social gatherings, group settings convened to address particular issues, discussions between neighbours, phone trees, seeking advice from experienced landowners, 
and groups formed around shared hobbies and interests - landowners learnt about land management issues, adjusted their own practices, and learnt about and formed the land and resource management institutions and norms of their area.

\section{Methodology}

The data for this study was derived from a survey of rural landholders in Kiama Local Government Area (LGA). The survey was designed with the following objectives:

- Collect data about land use and natural resource management by landholders.

- Identify and compare different types of landholders (e.g. lifestyle farmers and professional farmers).

- Address concerns raised by Kiama Municipal Council (KMC) and associated bodies such as the Illawarra District Noxious Weeds Authority (IDNWA).

Kiama LGA is south of Sydney on the NSW south coast. It is readily accessible from Sydney and Wollongong and is an attractive area with open farmland, forest, escarpment, and coastal lands. The area has seen significant growth in lifestyle oriented rural landownership and a relative decline in the area's agricultural sector (Gill, Klepeis, and Chisholm 2010). Rural residential land use is increasingly dominant in Kiama LGA. A 2006 study of land use in the LGA found that $62 \%$ of rural lots, comprising $43.1 \%$ of the area of rural land in the LGA were used for rural residential purposes (Edge Rural Planing 2006). Most of the remainder was used for dairying (26.2\% of the rural land) and extensive agriculture (22.8\% of the rural land). In terms of farm numbers at least, dairying is in long term decline in the area, particularly since a round of deregulation in 2000.

Following the methodologies of Dillman et al (2009) a survey was developed and sent to rural landholders in the Kiama LGA. The survey questions were developed on the basis of previous qualitative research (Gill, Klepeis, and Chisholm 2010; Klepeis, Gill, and Chisholm 2009) in the region and in Australia (for example, Mendham and Curtis 2010) and with the assistance of staff at Kiama Municipal Council (KMC), the Small Farms Network, the Southern Rivers Catchment Management Authority, the NSW Department of Primary Industry (DPI) and the Illawarra District Noxious Weeds Authority. The survey was sent to all rural ratepayers in the Kiama LGA by Kiama KMC, a total of 1000 individuals. Rural ratepayers received a pre-survey post-card, the survey (together with a teabag and packet of biscuits stapled to the survey) itself a week later, and a follow-up reminder a week after the 
survey. Three hundred and fifty-five (355) completed surveys were returned for a response rate of $35.5 \%$.

The survey covered a range of land use and natural resource management issues as well as questions designed to discern types of landowners, principally to identify those best identified as lifestyle or amenity-oriented rural landholders who make no or little income from their land, in comparison to landholders best seen as farmers who make all or a substantial proportion of their income from their land. These distinctions are not hard and fast; there are amenity landholders who do not depend on income derived from land but who may have larger holdings and derive relatively significant income from primary production. In contrast, many commercial farmers are dependent on off farm income and may regard farming as a lifestyle choice. A common way to distinguish between lifestyle owner and other rural landholder types is by the size of their land and land-based income earnings (Hollier and Reid 2007; Pannell and Wilkinson 2009). Others distinguish between commercial farmers and graziers on one hand, and various types of lifestyle landholders on the other. Common lifestyle categories include hobby farmers, investors, recreationalists, rural retreaters, amenity buyers, part-time farmers/ranchers (Gosnell, Haggerty, and Travis 2006; Hollier and Reid 2007; Klepeis, Gill, and Chisholm 2009). In related work, we have also categorised lifestyle owners according to a three-fold stewardship typology (Gill, Klepeis, and Chisholm 2010), an exercise that reinforced the diversity of types of landholders and the potential subtle differences within broader landholder types.

Recognising this diversity and the difficulty, indeed the futility, of precisely defining landowner types, our survey included various questions that allow us to characterise landowner types. In this paper we draw on two of these questions to distinguish between lifestylers and farmers and to compare the results for each approach. The first is a question in which respondents were asked to select a land use description that best described their land use. The options were: my land is used primarily for the conservation of native plants and animals, my land is used primarily for recreation or as a rural retreat, my land is used primarily for earning a living, other. Reponses to the 'other' option almost universally corresponded to one of the other options and they were recoded accordingly. In this paper, to distinguish between lifestylers and farmers, we have recoded the responses to this question into two categories labelled 'conservation/recreation' and 'earn a living'. The second question we analyse here asked respondents to select from four options regarding the 
importance of land-based income. The options were: production from my land serves as the primary source of income for my household, production from my land provides a significant secondary source of income for my household, production from my land provides a minor source of income for my household, production from my land generates no income for my household. For this paper we have recoded these options into two categories labelled 'production from land provides little or no income', a group we assume here corresponds mainly to lifestylers, and 'production from land is the primary source of income', a group we assume here corresponds largely to farmers. In the text for both recoded characterisations we refer to the former group as lifestylers and the latter groups as farmers. To separate out famers from lifestylers as clearly as possible in analysis using the income criteria we have only included as farmers those who selected 'production from my land serves as the primary source of income for my household'.

In this paper we analyse respondents along these two lines of data for two questions relating to sources of advice. First we asked respondents to indicate from a list of possible contacts in the region which of these they had been in contact with regarding land management. We then asked them to nominate which of these contacts was their most important contact. As the respondent numbers in the results below show, the first part of this question was answered by a large majority of respondents, whereas the second part was answered by a large minority, with a relatively good response from lifestylers but unfortunately only by a small number of farmers. This has implications for our comparison of landowner types - unless specified otherwise, we use Fisher's exact test instead of the Chi square statistic. In the second question we use in this paper, we asked respondents to nominate their source of information on revegetation as well as their most important source of such advice. For this latter question, lifestylers responded in good numbers but farmers again responded in low numbers. Thus in this paper, our findings are most reliable for the first, more open, part of our questions. For the questions where we asked about the most important contacts and sources, our data is most reliable for lifestylers. Further data is available in Gill and Klepeis (2011) 


\section{Results}

The majority (84.8\%) of respondents reported using their land for rural retreat/recreation and conservation of native plants and animals (lifestylers). Only about 15\% of respondents reported using their land primarily to earn a living (farmers). Production from the land was reported as the primary source of income for less than one-tenth (8.3\%) of the respondents (farmers). These respondents were mainly dairy farmers and beef cattle producers (mean annual value of production, $\$ 143100$ and $\$ 9650^{1}$ respectively). This group of landholders have also, on average, owned their land three times as long as lifestylers for whom the land provides little or no income (91.7\% of our respondents). Forty percent of lifestylers do undertake some grazing and the mean annual value of their beef production was $\$ 1397$. Most were undertaking grazing for non-monetary reasons such as maintaining the landscape, providing learning and recreational opportunities for their children or grandchildren, or aesthetics. The average age of each group of landholders was similar (61 years and 59 years respectively).

\subsection{Landholders' contacts for land management advice}

Initially, respondents were asked to select from a list as many contacts for land management as applicable to them. Table one shows that neighbours were an important contact for both groups and were the contact most often selected by lifestylers. Friends and family were also important, though more so for those who make a living and who presumably can draw on family members with farming experience. This difference between the groups was statistically significant for friends/family as they were also for industry group, the Southern Rivers Catchment Management Authority, government agencies, rural stores, and contractors (for best description of land use only). In these instances farmers were more likely to select these as a contact for land management. Overall, landowners are in contact with diverse individuals and organisations and many were selected by more than ten percent of both landowners. It is clear, however, that various personal contacts such as neighbours and contractors are important contacts for land management. It is also clear that there are differences between the types of landholders. We examine this further below.

We then asked respondents to select their most important contact for land management. Table two shows that although both groups chose friends/family as their most important contact, farmers were more likely to turn to their friends and family for land management advice. 
Lifestyle farmers, on the other hand, favoured contacts such as neighbours and contractors as well as friends/family. Lifestylers also ranked rural stores relatively highly as their most important contact and farmers identified state government agencies as a relatively important source of advice. The contact nominated by respondents was significantly related to landholder types based on land use description $\left(\chi^{2}(10, N=101)=24.65, p=.000\right)$ and income generated from the land $\left(\chi^{2}(9, N=101)=19.4, p=.000\right)$.

To further generalise with respect to which type of contact is most important to landholders, the different nominated contacts were merged into three groups (Personal, Nongovernment and Government contacts). As the name of the group implies, contacts like contractors, neighbours and family/friends were classified as 'Personal' contacts. 'Nongovernment' contacts refer to non-governmental organisations such as Landcare, while 'Government' contacts refer to contacts such as state agencies, local government or the CMA.

As illustrated in table 3, based on the categorisation of land use description, lifestylers were more likely (82.6\%) to favour 'Personal' contacts than professional farmers, although the majority (60\%) of the latter group also considered 'Personal' contacts to be most important to them. Farmers were also more likely (24\% and $16 \%$ respectively) to nominate 'Non-government' and 'Government' contacts than lifestyle farmers. These differences between landholders types are statistically significant $\left(\chi^{2}\left(2, N=117^{2}\right)=12.17, p=.003\right)$.

In the categorisation of landholders into groups based on income earnings from their land, 'Personal' contacts were also nominated as the most important contact for both landholder groups. Lifestylers were, however, more likely (81.2\%) to favour 'Personal' contacts than farmers (68.8\%). On the other hand, farmers were more inclined to nominate 'Non-government' (25.0\%) and 'Government' (6.25\%) contacts than are lifestylers. In this case however, the differences between the landholder groups were not statistically significant $\left(\chi^{2}(2, N=117)=1.381, p=.420\right)$.

\subsection{Landholders' most important contact for revegetation advice}

Revegetation for various purposes is a key element of contemporary land management. To gain insight into where farmers and lifestylers obtain advice regarding revegetation on their land, respondents were asked several questions about advice for tree. 
planting. The results show that, overall, all landholders are almost evenly split as to whether they obtain advice at all. Forty-eight percent indicated that they do not obtain advice and fifty-two percent indicated that they do $(n=337)$. As shown in table four, when we break this down into landholder types, lifestylers are more likely to seek advice than farmers, although significant proportions of each do not seek advice. A chi-square test showed that this difference is statistically significant for best description of land use but not for the importance of land-based income; respectively $\chi^{2}(1, N=326)=5.7, p=0.017$ and $\chi^{2}(1, N=324)=3.5$, $p=0.62$. When we repeated this test by recoding primary and significant secondary land income together (rather than separating out primary income significance as throughout this paper) and comparing these respondents to those for whom land-based income was of minor or no importance, the proportions for each groups across the two responses were similar (Gill and Klepeis 2011), however, the difference between the two groups was statistically significant $-\chi^{2}(1, N=324)=7.2, p<0.007$ - bolstering the general finding of difference between farmers and lifestylers.

We then asked respondents to nominate from a list of contacts the one they considered most important for revegetation. In the categorisation of landholders based on their best description of land use, both groups favoured books, magazines and the internet as their most important source of advice. However, as illustrated in table 5, farmers were more likely (41.7\%) to obtain information on revegetation from books, magazines and the internet. Lifestylers, on the other hand, were just as likely to seek advice from nurseries (23.9\%) as from books, magazines and the internet. Other choices favoured by farmers were the Southern Rivers Catchment Management Authority (SRCMA) and to replicate what grows locally. Groups such as Landcare were not identified as the most important contact for this advice by large proportions of either group. The results show that the two groups of landholders are significantly different in their source of advice for revegetation $\left(\chi^{2}(11, N=\right.$ 100) $=29.33, p=.005)$.

In the categorisation of landholders into groups based on income earnings, only four of the listed contacts were nominated by farmers; nurseries, Landcare groups, SRCMA and books/magazines/internet. Table 5 illustrates that about two-thirds of farmers were equally likely to turn to the SRCMA as they were to depend on books/magazines/internet for revegetation advice. They were equally likely to go to nurseries $(16.7 \%)$ as to groups such as Landcare (16.7\%) for revegetation advice. Lifestylers, on the other hand, favoured choices like books/magazines/internet (25.5\%), nurseries (22.3\%) and to replicate what grows locally 
(11.7\%). Lifestylers in this category were less likely than farmers to depend on books, magazines and the internet. They were, however, more likely to go to nurseries for revegetation advice than farmers. Collectively, personal contacts such as neighbours, friends and contractors were the most important contact for $22.7 \%$ of lifestylers. The results show that the two groups of landholders are significantly different in their source of advice for revegetation $\left(\chi^{2}(11, N=100)=35.57, p=.010\right)$.

Overall, these results for revegetation highlight a diversity of sources for advice and information. However, in general, they also highlight that many landholders are not seeking advice. Moreover, these results indicate that in addition to personal contacts, landowners are relying heavily on sources such as book, magazines, the internet and nurseries rather than sources such as Landcare and the SRCMA who can provide expert and experienced advice for localities. It is possible that landholders are accessing web and published resources from such organisations but further research would be required to investigate this and the identity of the sources that are popular and influential.

\section{Discussion}

Despite the differences in nominated contacts between landholder types, there is a clear preference by both groups for personal contacts like neighbours, contractors and family/friends. This has previously been shown for farmers who prefer to obtain information from people such as contractors, neighbours, family and friends to whom they can relate and with whom are likely to share the same experiences (Allan 2005; Kilpatrick and Rosenblatt 1998). Our survey data shows that this is the case for lifestylers as well.

In other respects, this study corroborates the findings of international (Gosnell and Travis 2005) and Australian research (Mendham and Curtis 2010; Hollier and Reid 2007) which has found that lifestyle farmers significantly differ from professional farmers in a number of ways. One of the ways in which landholders differ is the networks they are part of and from which they obtain advice on land management and revegetation. Our analysis provides further detail regarding the sources used by lifestylers and explicitly compares them to farmers. Both of these groups of landowners access diverse sources of advice and draw most heavily on personal contacts. Farmers and lifestylers, however, differ to some extent in the sources of advice that they access. Reflecting both their own needs and likely that of the 
targeting and contemporary provision of services, farmers make more use of government agencies (including the SRCMA), industry groups, rural suppliers, and contractors. This resonates with farmers' preference for tried and proven land management practices (Allan 2005).

Lifestylers make use of a slightly more diverse range of sources, especially for revegetation, but make relatively greater use of personal contacts such as neighbours, family/friends, contractors, and, to a lesser extent, rural suppliers. Contractors are a source for both groups of landholders and overall more farmers selected contractors as a source. A relatively large number of lifestylers, however, selected contractors as their key source of advice. This likely reflects lifestylers employing contractors for tasks for which they lack the skills or equipment, some of which is expensive (e.g. tractors). Based on observations during our previous research (Gill, Klepeis, and Chisholm 2010; Klepeis, Gill, and Chisholm 2009), such contractors can be local farmers earning secondary income sources, highlighting not only the role of contractors in general in influencing lifestylers, but a potentially significant point of contact between the groups of landholders. Further, a key point of difference was the high reliance of lifestylers on neighbours as contacts for land management in general. In contrast farmers, who also generally relied heavily on personal contacts, relied more significantly on family/friends. In keeping with the relatively high importance of personal contacts for them, lifestylers, however, also nominated family/friends as an important contact. These results emphasise the need for landholder engagement and extension to emphasise relationships among landowners and work to foster these and provide support for the argument of Meadows et al (2012) that government should provide a 'background' facilitator role and foster peer mentoring networks. There are clearly connections here to existing NRM programs which include such goals (e.g. the funding of Landcare associations and their work). There remain, however, opportunities to more explicitly explore the nature and the learning and management outcomes of these personal contacts and relationships, and their relationships to existing institutions such as Landcare or 'bridging' organisations such as the Small Farms Network in our study area. This is especially the case for lifestylers as they learn about land management. Further, the significance of personal contacts, and of neighbours for lifestylers, once again brings in critical focus concerns about the character of social fragmentation in landscapes (Epanchin-Niell et al. 2010; including by us, Klepeis, Gill, and Chisholm 2009) and suggests that diverse landholders do interact with each other about land management issues. The extent to which this is leading to deeper engagement where 
they learn to collectively negotiate changed circumstances and develop new norms and institutions, as found by Larsen et al (2011), is beyond our data but a significant question for land management in regional Australia and elsewhere. Further, the reliance on neighbours suggests that lifestylers interact with, and learn from, a range of landholders, probably including neighbours who are farmers.

There are also clearly differences in where landholders go for advice for different issues. For example, for land management in general, lifestylers rely on personal contacts, but for revegetation they relied most heavily on nurseries and books/magazines/internet. As in gardening (Groves, Boden, and Lonsdale 2005), the role of the horticultural/plant industry appears to be significant in influencing management actions by landholders, especially lifestylers, and further research into the nature of advice from nurseries and its role in decision-making would be beneficial. Further, about ten percent of lifestylers nominated 'replicate what grows locally' as their key source for revegetation, highlighting the potential significance of the nature and pathways of decision-making via observation and experiential learning. Farmers also relied on books/magazines/internet but also favoured the Catchment Management Authority and Landcare as sources of advice to a relatively greater extent compared to lifestylers. Many of both groups do not seek advice for revegetation.

\section{Conclusion}

This paper aims to identify and discuss sources of advice for land management among lifestylers, to compare these sources with those of farmers, and to compare approaches to characterising landholders. For our two characterisations of landholders, results were generally similar and, in most cases, statistically significant whether we used land use or land-based income significance. Both approaches are useful in this field of research but we suggest that future survey-based research could be based on scale development to more subtly explore the significance of diverse landownership motivations and activities. Alternatively, it could use more direct measures of land-based income such as ordinal production value data. Our landholder categories provide more explicit and direct land use related characterisation of landholders than previous research but retain ambiguities that could be improved on. 
More generally the results show clear differences between landholders but also that the more things change, the more they stay the same. Like other researchers, we do find that lifestylers and farmers are different; in our case, different in their relative reliance on various sources of advice. However, we also find that they are the same in their reliance on types of sources. Thus, in general, both lifestylers and farmers rely on diverse sources for land management advice and information. For their most important sources, they both rely predominantly on personal sources of advice such as neighbours, family, friends, and contractors. More specifically however, farmers tend to rely on family and friends (as well as agencies and industry groups to a greater extent) whereas lifestylers rely to a greater extent on neighbours and contractors. This suggests reliance on different (and possibly intersecting) networks but comparable processes of personal interaction and learning. It also suggests that insights from the extension literature regarding the critical importance of socio-cultural processes in the promotion and adoption of practices by landholders are broadly applicable to lifestylers as well as farmers. It does, however, also suggest the need for engagement practicioners to be aware of, and work to, the different networks that lifestylers are part of.

Our findings also trouble the notion of a simple and one-dimensional process of fragmentation in landscapes characterised by land ownership and land use change due to amenity migration and the relative decline of agriculture. The process of fragmentation has been depicted in terms such as increased heterogeneity in land use and management and in terms of increases in the sheer number of landowners that extension staff must deal with. It is also associated with the suggestion that as farming declines and diverse lifestylers move in, 'community' is lost or somehow degraded, including in the sense that a community of landholders with shared norms, histories, and land uses declines or disappears. These are not trivial issues at all and are often keenly felt, especially for remaining farmers. However, our findings corroborate other research that has found that landowners in amenity migration areas are developing networks that are consistent with the emergent character of landscapes in such areas, including networks that operate across landholder types. Thus we suggest that certain types of fragmentation (e.g. cadastral) need to be seen as part of ownership transitions that are complex, uneven, and multiscalar (Abrams et al. 2012), encompassing both direct, material change such as subdivision, as well as complex and always evolving interactions between landholders and other actors. 


\section{Notes}

1. Our figures suggest that farms in the area are relatively small, particularly for beef cattle. This is however, consistent with 2010-2011 Agricultural Census data which shows that the average beef cattle herd in Kiama was only 48 head (Australian Bureau of Statistics 2012). For dairy farmers, the picture is less clear. Although herd size in the area is on par with the NSW average (Australian Bureau of Statistics 2012; McKenzie 2013) it seems likely our dairy farmer respondents are relatively small dairy farmers for the Kiama area. It is also possible that some farmers have provided net farm income rather than the gross value of production in their responses. Alternatively, we also know from earlier fieldwork (Gill, Klepeis, and Chisholm 2010) and long term networks in the area (Gill, Adams, and Eriksen 2012) that some older farmers and farmers with low debt have maintained dairy production at what are now low levels for the industry or developed small beef herds after the 2000 round of dairy restructuring. Some of these farmers are effectively semi-retired; others have diversified into work such as contracting. Such respondents are likely to have identified as farmers in terms of land use in completing the survey even if their landbased income is now relatively small. This may explain the difference between those who responded that their land is primarily used to make a living and those who said their land was a significant source of income.

2. The number of respondents is 117 here rather than 101 as for the data in table two as we recoded 'other' responses in the process of recoding the data for these more general categories of contacts. 
Table 1. Percentage of landholders by contact regarding land/NRM management. Asterisks denote statistically significant differences (Chi square) at the $\mathrm{p}=0.05$ level)

\begin{tabular}{|c|c|c|c|c|c|}
\hline Type of Contact & $\begin{array}{c}\text { Conservation/ } \\
\text { Recreation } \\
(n=290)\end{array}$ & $\begin{array}{l}\text { Make a Living } \\
\text { from Land } \\
(n=52)\end{array}$ & $\begin{array}{l}\text { Type of } \\
\text { Contact }\end{array}$ & $\begin{array}{l}\text { Production from } \\
\text { land provides little } \\
\text { or no income } \\
(n=310)\end{array}$ & $\begin{array}{c}\text { Production from } \\
\text { land is the } \\
\text { primary source } \\
\text { of income ( } n=28)\end{array}$ \\
\hline Neighbours & 30.7 & 38.5 & Neighbours & 30.3 & 42.9 \\
\hline $\begin{array}{l}\text { Industry } \\
\text { Group* }\end{array}$ & 3.1 & 32.7 & $\begin{array}{l}\text { Industry } \\
\text { Group* }\end{array}$ & 4.5 & 39.3 \\
\hline $\begin{array}{l}\text { Small Farm } \\
\text { Network }\end{array}$ & 10.7 & 19.2 & $\begin{array}{l}\text { Small Farm } \\
\text { Network }\end{array}$ & 11.9 & 10.7 \\
\hline $\begin{array}{l}\text { Groups such as } \\
\text { Landcare }\end{array}$ & 13.8 & 15.4 & $\begin{array}{l}\text { Groups such as } \\
\text { Landcare }\end{array}$ & 12.9 & 21.4 \\
\hline $\begin{array}{l}\text { Southern Rivers } \\
\text { CMA* }\end{array}$ & 8.3 & 17.3 & $\begin{array}{l}\text { Southern } \\
\text { Rivers CMA* }\end{array}$ & 7.7 & 25.0 \\
\hline Friends/Family* & 26.6 & 48.1 & $\begin{array}{l}\text { Friends/Family } \\
*\end{array}$ & 28.1 & 53.6 \\
\hline $\begin{array}{l}\text { Conservation } \\
\text { Volunteers Aust. }\end{array}$ & 3.1 & 1.9 & $\begin{array}{l}\text { Conservation } \\
\text { Volunteers } \\
\text { Aust. }\end{array}$ & 2.9 & 3.6 \\
\hline $\begin{array}{l}\text { Government } \\
\text { Agency* }\end{array}$ & 4.5 & 30.8 & $\begin{array}{l}\text { Government } \\
\text { Agency* }\end{array}$ & 5.5 & 35.7 \\
\hline Council & 5.5 & 11.5 & Council* & 5.2 & 17.9 \\
\hline $\begin{array}{l}\text { Rural Supply } \\
\text { Store* }\end{array}$ & 18.6 & 44.2 & $\begin{array}{l}\text { Rural Supply } \\
\text { Store* }\end{array}$ & 20.0 & 57.1 \\
\hline Contractor* & 25.5 & 44.2 & Contractor & 27.4 & 42.9 \\
\hline Other & 9.0 & 11.5 & Other & 9.0 & 14.3 \\
\hline
\end{tabular}


Table 2. Landholders' most important source of land management advice (percentage of landholders)

\begin{tabular}{|c|c|c|c|c|}
\hline & \multicolumn{2}{|c|}{ Land-based income } & \multicolumn{2}{|c|}{ Best description of land use } \\
\hline $\begin{array}{c}\text { Most } \\
\text { important } \\
\text { contact }\end{array}$ & $\begin{array}{l}\text { Production from } \\
\text { land provides } \\
\text { little or no } \\
\text { income ( } n=88)\end{array}$ & $\begin{array}{l}\text { Production } \\
\text { from land is } \\
\text { the primary } \\
\text { source of } \\
\text { income } \\
(n=13)\end{array}$ & $\begin{array}{l}\text { Conservation/Recreation } \\
\qquad(n=79)\end{array}$ & $\begin{array}{l}\text { Earn a } \\
\text { living } \\
(n=22)\end{array}$ \\
\hline Neighbours & 26.1 & 0.0 & 27.8 & 4.5 \\
\hline Industry & 0.0 & 0.0 & 0.0 & 0.0 \\
\hline Small Farm & 4.5 & 7.7 & 3.8 & 9.1 \\
\hline $\begin{array}{l}\text { Groups such as } \\
\text { Landcare }\end{array}$ & 6.8 & 0.0 & 6.3 & 4.5 \\
\hline SRCMA & 0.0 & 7.7 & 0.0 & 4.5 \\
\hline Friends/Family & 30.7 & 69.2 & 30.4 & 50.0 \\
\hline $\begin{array}{l}\text { Conservation } \\
\text { Volunteers } \\
\text { Australia }\end{array}$ & 1.1 & 0.0 & 1.3 & 0.0 \\
\hline Govt. Agency & 3.4 & 0.0 & 0.0 & 13.6 \\
\hline Council & 0.0 & 0.0 & 1.3 & 0.0 \\
\hline Store & 2.3 & 7.7 & 2.5 & 4.5 \\
\hline Contractor & 15.9 & 7.7 & 17.7 & 4.5 \\
\hline Other & 9.1 & 0.0 & 8.9 & 4.5 \\
\hline
\end{tabular}


Table 3. Landholders' most important source of land management advice by generalised source (percentage of landholders)

\begin{tabular}{|l|c|c|c|c|}
\hline & \multicolumn{2}{|c|}{ Land-based income } & \multicolumn{2}{c|}{ Best description of land use } \\
\hline $\begin{array}{c}\text { Most } \\
\text { important } \\
\text { contact }\end{array}$ & $\begin{array}{c}\text { Production from } \\
\text { land provides } \\
\text { little or no income } \\
(\mathbf{n = 1 0 1 )}\end{array}$ & $\begin{array}{c}\text { Production from } \\
\text { land is the primary } \\
\text { source of income } \\
(\boldsymbol{n = 1 6 )}\end{array}$ & $\begin{array}{c}\text { Conservation/Recreation } \\
(\boldsymbol{n = 9 2 )}\end{array}$ & $\begin{array}{c}\text { Earn } \\
\text { a } \\
\text { living } \\
(\boldsymbol{n}=\mathbf{2 5})\end{array}$ \\
\hline Personal & 81.2 & 68.8 & 82.6 & 60.0 \\
\hline Non-Govt. & 15.8 & 25.0 & 16.3 & 24.0 \\
\hline Govt. & 3.0 & 6.3 & 1.1 & 16.0 \\
\hline
\end{tabular}

Table 4 Percentage of landholders who seek advice for revegetation

\begin{tabular}{|l|c|c|c|c|}
\hline & $\begin{array}{c}\text { Production from } \\
\text { land provides } \\
\text { little or no } \\
\text { income }(\boldsymbol{n}=\mathbf{2 9 8})\end{array}$ & $\begin{array}{c}\text { Production from } \\
\text { land is the } \\
\text { primary source } \\
\text { of income }(\boldsymbol{n}=\mathbf{2 6})\end{array}$ & $\begin{array}{c}\text { Conservation/Recreation } \\
(\boldsymbol{n}=\mathbf{2 7 7})\end{array}$ & $\begin{array}{c}\text { Make a Living } \\
\text { from Land } \\
(\boldsymbol{n}=\mathbf{4 9})\end{array}$ \\
\hline Yes & 53.7 & 34.6 & 55.2 & 36.7 \\
\hline No & 46.3 & 64.5 & 44.8 & 63.3 \\
\hline
\end{tabular}


Table 5. Landholders' most important source of revegetation advice (percentage of landholders)

\begin{tabular}{|c|c|c|c|c|}
\hline \multirow[b]{2}{*}{$\begin{array}{c}\text { Source of } \\
\text { revegetation } \\
\text { advice }\end{array}$} & \multicolumn{2}{|c|}{ Land-based income } & \multicolumn{2}{|c|}{ Best description of land use } \\
\hline & $\begin{array}{c}\text { Production } \\
\text { from land } \\
\text { provides little } \\
\text { or no income } \\
\quad(n=94)\end{array}$ & $\begin{array}{c}\text { Production } \\
\text { from land is } \\
\text { the primary } \\
\text { source of } \\
\text { income }(n=6)\end{array}$ & $\begin{array}{c}\text { Conservation/Recreation } \\
\qquad(n=88)\end{array}$ & $\begin{array}{l}\text { Earn a } \\
\text { living } \\
(n=12)\end{array}$ \\
\hline $\begin{array}{l}\text { Rural supply } \\
\text { store }\end{array}$ & 1.1 & 0.0 & 1.1 & 0.0 \\
\hline Nurseries & 22.3 & 16.7 & 23.9 & 8.3 \\
\hline Neighbours & 7.4 & 0.0 & 8.0 & 0.0 \\
\hline Council & 1.1 & 0.0 & 0.0 & 8.3 \\
\hline $\begin{array}{c}\text { Groups such as } \\
\text { Landcare } \\
\end{array}$ & 5.3 & 16.7 & 5.7 & 8.3 \\
\hline Friend or family & 8.5 & 0.0 & 9.1 & 0.0 \\
\hline $\begin{array}{c}\text { State } \\
\text { government }\end{array}$ & 1.1 & 0.0 & 1.1 & 0.0 \\
\hline $\begin{array}{c}\text { Southern Rivers } \\
\text { CMA }\end{array}$ & 0.0 & 33.3 & 0.0 & 16.7 \\
\hline $\begin{array}{c}\text { Replicate what } \\
\text { comes up/grows } \\
\text { locally }\end{array}$ & 11.7 & 0.0 & 10.2 & 16.7 \\
\hline $\begin{array}{c}\text { Books, } \\
\text { magazines, } \\
\text { internet }\end{array}$ & 25.5 & 33.3 & 23.9 & 41.7 \\
\hline Contractor & 5.3 & 0.0 & 5.7 & 0.0 \\
\hline Other & 10.6 & 0.0 & 11.4 & 0.0 \\
\hline
\end{tabular}




\section{References}

Abrams, J., H. Gosnell, N. Gill, and P. Klepeis. 2012. "Re-creating the Rural, Reconstructing Nature: An International Literature Review of the Environmental Implications of Amenity Migration." Conservation and Society 10 (3):270-84.

Abrams, J. B., and H. Gosnell. 2012. "The politics of marginality in Wallowa County, Oregon: Contesting the production of landscapes of consumption." Journal of Rural Studies 28 (1):3037.

Allan, J. 2005. "Farmers as learners: Evolving identity, disposition and mastery through diverse social practices." Rural Society 15 (1):4-21.

Argent, N. 2011. "Trouble in Paradise? Governing Australia's multifunctional rural landscapes." Australian Geographer 42 (2):183-205.

Australian Bureau of Statistics. 2012. Agricultural Commodities, Australia, 2010-11 (Cat. No. 7121.0). Canberra: Australian Bureau of Statistics.

Barr, N. 2010. The House on the Hill: The Transformation of Australia's Farming Communities. Canberra: Land and Water Australia/Halstead Press.

Curry, G. N., G. Koczberski, and J. Selwood. 2001. "Cashing out, cashing in: rural change on the south coast of Western Australia." Australian Geographer 32 (1):109-124.

Dillman, D. A., J. Smyth, and L. M. Christian. 2009. Internet, Mail, and Mixed-mode Surveys: The Tailored Design Method. New Jersey: John Wiley.

Dwyer, J. F., and G. M. Childs. 2004. "Movement of people across the landscape: a blurring of distinctions between areas, interests, and issues affecting natural resource management." Landscape and Urban Planning 69:153-164.

Edge Rural Planing. 2006. Kiama Rural Lands Study. Kiama: Kiama Municipal Council.

Epanchin-Niell, R. S., M. B. Hufford, C. E. Aslan, J. P. Sexton, J. D. Port, and T. M. Waring. 2010. "Controlling invasive species in complex social landscapes." Frontiers in Ecology and the Environment 8 (4):210-26.

Gill, N., M. Adams, and C. Eriksen. 2012. "Engaging with the (Un)familiar: Field Teaching in a Multi-Campus Teaching Environment." Geography in Higher Education 36 (2):259-275.

Gill, N., and P. Klepeis. 2011. Data Summary: Living, Working, and Playing on the Land Survey. http://socialsciences.uow.edu.au/ausccer/UOW002998.html.

Gill, N., P. Klepeis, and L. Chisholm. 2010. "Stewardship among lifestyle oriented rural landowners." Journal of Environmental Planning and Management 53 (3):317-334.

Gosnell, H., J. H. Haggerty, and W. R. Travis. 2006. "Ranchland ownership change in the Greater Yellowstone ecosystem, 1990-2001: Implications for conservation." Society and Natural Resources 19:743-758.

Gosnell, H., and W. R. Travis. 2005. "Ranchland ownership dynamics in the Rocky Mountain West." Rangeland Ecology \& Management 58 (2):191-198.

Graham, S. 2013. "Three cooperative pathways to solving a collective weed management problem." Australasian Journal of Environmental Management 20 (2):116-129.

Groves, R. H., R. Boden, and W. M. Lonsdale. 2005. Jumping the Garden Fence: Invasive Garden Plants in Australia and their Environmental and Agricultural Impacts. Sydney: CSIRO Report for WWF-Australia, WWF-Australia.

Hollier, C., and M. Reid. 2007. Small Lifestyle Farms: Improving Delivery Mechanisms for Sustainable Land Management. Canberra: Rural Industries Research and Development Corporation.

Kilpatrick, S., and T. Rosenblatt. 1998. "Information vs training: Issues in farmer learning." The Journal of Agricultural Education and Extension 5 (1):39-51.

Klepeis, P., N. Gill, and L. A. Chisholm. 2009. "Emerging amenity landscapes: Invasive weeds and land subdivision in rural Australia." Land Use Policy 26 (2):380-392.

Lake, E. 2009. Restoration on Private Land: Management Practices and Motivation of Landowners. A Case Study of Jamberoo Valley, NSW, School of Earth and Environmental Science, University of Wollongong, Wollongong. 
Larsen, S. C., M. Foulkes, C. J. Sorenson, and A. Thompson. 2011. "Environmental learning and the social construction of an exurban landscape in Fremont County, Colorado." Geoforum 42:8393.

Larsen, S. C., C. Sorenson, D. McDermott, J. Long, and C. Post. 2007. "Place Perception and Social Interaction on an Exurban Landscape in Central Colorado." The Professional Geographer 59 (4):421 - 433.

McKenzie, J. 2013. Overview of the NSW Dairy industry. Orange: NSW Department of Primary Industries.

Meadows, J., N. Emtage, and J. Herbohn. 2014. "Engaging Australian small-scale lifestyle landowners in naturalresource management programmes - Perceptions, past experiencesand policy implications." Land Use Policy (36):618-627.

Meadows, J., J. Herbohn, and N. Emtage. 2012. "Supporting Cooperative Forest Management among Small-Acreage Lifestyle Landowners in Southeast Queensland, Australia." Society \& Natural Resources:1-17.

Mendham, E., and A. Curtis. 2010. "Taking over the reins: trends and impacts of changes in rural property ownership." Society and Natural Resources 23 (7):653-668.

Pannell, D., G. Marshall, N. Barr, A. Curtis, F. Vanclay, and R. Wilkinson. 2006. "Understanding and Promoting adoption of Conservation technologies by Rural Landholders." Australian Journal of Experimental Agriculture 46:1407-1424.

Pannell, D., and R. Wilkinson. 2009. "Policy mechanism choice for environmental management by non-commercial "lifestyle" rural landholders." Ecological Economics 68 (10):2679-2687.

Race, D., G. W. Luck, and R. Black. 2011. "Patterns, drivers and implications of demographic change in rural landscapes." In Demographic Change in Australia's Rural Landscapes: Implications for Society and the Environment, edited by G.W. Luck, D. Race and R. Black, 1-22. Dordrecht and Collingwood: Springer and CSIRO Publishing.

Robbins, P., K. Meehan, H. Gosnell, and S. J. Gilbertz. 2009. "Writing the New West: A Critical Review." Rural Sociology 74 (3):356-382.

Walker, P., and P. T. Hurley. 2011. Planning paradise: politics and visioning of land use in Oregon Tuscon: University of Arizona Press. 